\title{
Manajemen Lingkungan Pendidikan dalam Perspektif Islam
}

\author{
DEVI ARISANTI \\ Fakultas Tarbiyah dan Keguruan Universitas Islam Negeri (UIN) Sultan Syarif Kasim Riau \\ Jl. Kaharuddin Nasution No. 113 Perhentian Marpoyan Pekanbaru 28284 \\ e-mail: devi_arisanti@yahoo.co.id
}

\begin{abstract}
Abstrak: Pendidikan islam selama ini telah diupayakan sedemikian rupa pengelolaannya agar tercapainya tujuan pendidikan secara maksimal. Pada pelaksanaannya, pendidikan islam tentu saja tidak terlepas dari manajemen dan lingkungan disekitarnya. Dalam manajemen diperlukan adanya strategi yang tepat, dan tim yang solid sehingga tujuan bisa tercapai. Sedangkan strategi pada manajemen itu sendiri bereaksi hanya kepada lingkungan yang berwujud manusia yaitu masyarakat. Baik manajemen maupun lingkungan sekolah memiliki interaksi dan pengaruh yang kuat terhadap proses dalam pengelolaan pendidikan termasuk pendidikan islam. Lingkungan pendidikan islam sebaiknya dikelola sedemikian rupa sehingga tujuan pendidikan itu dapat terwujud. Dengan adanya interaksi yang baik serta dukungan dari masyarakat dan pihak yang terkait dengan lingkungan pendidikan tersebut, diharapkan sekolah akan menjadi lebih maju. Dengan kata lain, kerjasama yang baik baik dari guru, orang tua, dewan pendidikan, komite dan masyarakat disekitar lingkungan sekolah dipercaya akan mampu mengembangkan potensi yang dimikili dan memajukan kualitas pendidikan islam.
\end{abstract}

Kata Kunci: Manajemen, lingkungan pendidikan, pendidikan islam.

\section{PENDAHULUAN}

Pendidikan Islam dalam pengelolaannya memerlukan manajemen yang baik. Dalam pelaksanaannya tentulah memerlukan lingkungan yang kondusif demi terwujudnya pendidikan Islam yang bermutu.

Pada dasarnya setiap organisasi baik yang berskala besar, berskala menengah maupun kecil selalu berinteraksi dengan lingkungan dimana organisasi itu berada. Lingkungan adalah kekuatan-kekuatan yang berada di luar organisasi yang secara potensial baik langsung maupun tidak langsung akan mempengaruhi terhadap kinerja organisasi tersebut (Asnawir, 2006: 355).
Pendidikan di abad pengetahuan menuntut adanya manajemen pendidikan yang modern dan profesional dengan bernuansa pendidikan. Lembaga-lembaga pendidikan diharapkan mampu mewujudkan peranannya secara efektif dengan keunggulan dalam kepemimpinan, staf, proses belajar mengajar, pengembangan staf, kurikulum, tujuan dan harapan, iklim sekolah, penilaian diri, komunikasi dan keterlibatan orang tua dan masyarakat (Kunandar, 2007: 12).

Untuk membuat semua pihak terlibat dan merasa memiliki terhadap sekolah dibutuhkan suasana yang demokratis, dan semua pihak terlibat dalam proses pengambilan keputusan. 
Dari sinilah lalu muncul ide untuk mendesain sebuah "pendidikan berbasis masyarakat (community-basededucation). Plat form dasar pendidikan berbasis masyarakat adalah penguatan sistem pendidikan di masyarakat dengan serangkaian agenda, yaitu: Pertama, memobilisasi sumber daya setempat dan dari luar guna meningkatkan peran masyarakat untuk mengambil bagian yang lebih besar dalam perencanaan, implementasi, evaluasi penyelenggaraan pendidikan disemua jalur, jenjang, jenis dan satuan pendidikan. Kedua, menstimulasi perubahan sikap dan persepsi masyarakat terhadap rasa kemitraan, toleransi dan kesediaan menerima keragaman sosial budaya. Ketiga, mendukung masyarakat untuk mengambil peran yang jelas dalam pendidikan terutama orang tua dalam paket kebijakan desentralisasi. Keempat, mendorong peran masyarakat dalam mengembangkan inovasi kelembagaan untuk melengkapi, mempertegas peran sekolah, meningkatkan mutu relevansi, efisiensi manajemen pendidikan, dan membuka kesempatan sekolah yang lebih besar demi program belajar 9 tahun pendidikan dasar, pendidikan menengah, dan pendidikan tinggi (Fadjar, 2000: 91).

\section{Hakikat Manajemen dan Lingkungan Pendidikan Islam}

Manajemen berasal dari kata "managio" yang berarti pengurusan atau "managiare" yang berarti melatih dalam mengatur langkah-langkah. Manaajemen juga sering diartikan sebagai ilmu karena manajemen dipandang sebagai suatu bidang ilmu pengetahuan yang secara sistematis berusaha untuk memahami mengapa dan bagaimana orang bekerjasama.
Dikatakan sebagai profesi karena manajemen dilandasi oleh keahlian khusus untuk mencapai prestasi manajer daan para profesionalnya dituntut oleh suatu kode etik (Asnawir, 200625 ).

Sementara itu dalam Kamus Besar Bahasa Indonesia manajemen diartikan sebagai penggunaan sumber daya secara efektif untuk mencapai sasaran (Depdiknas, 2011: 708). Senada dengan hal itu menurut Johnson sebagaimana yang dikutip Pidarta manajemen adalah proses mengintegrasikan sumbersumber yang tidak berhubungan menjadi sistem total untuk menyelesaikan suatu tujuan. Yang dimaksud sumber disini ialah mencakup orang-orang, alat-alat, media bahan-bahan, uang dan sarana. Semuanya diarahkan dan dikoordinasi agar terpusat dalam rangka menyelesaikan tujuan (Pidarta, 2004: 3).

Secara bahasa manajemen mengandung arti kerja aktif yang bertanggungjawab, tidak sekedar untuk mengatur diri tetapi juga mengandung unsur sosial untuk memberikan pendidikan manajemen kepada orang lain, terutama kepada bawahannya.

Dari arti secara bahasa tersebut dapat dipahami bahwa manajemen merupakan kerja aktif, lawannya adalah pasif, dengan demikian manajemen adalah aktifitas aktif untuk mencapai sesuatu. Jika dalam sebuah organisasi tidak ada gerak aktif yang terus menerus dan terarah, maka organisasi tersebut belum terdapat manajemen yang baik.

G.R. Terry (1978) dalam Syahrizal Abbas menjelaskan bahwa manajemen merupakan penyusunan perencanaan, menggerakkan kegiatan dan pencapaian hasil yang diinginkan melalui pelibatan dan pemanfaatan sumber daya manusia. Konsep manajemen ini,

Jurnal Al-Thariqah Vol. 1, No. 1, Juni 2016 
menekankan pada kegiatan melaksanakan aktivitas tertentu dengan menggunakan tenaga orang lain. Dengan demikian dapat dikatakan bahwa manajemen adalah kemampuan atau kekuasaan untuk mengatur suatu usaha, dan bertanggung jawab atas keberhasilan dan kegagalan dari usaha tersebut (Abbas, 2008: 15).

Jika dihubungkan dengan manajemen pendidikan adalah manajemen yang diterapkan dalam pengembangan pendidikan. Dalam arti, ia merupakan seni dan ilmu mengelola sumber daya pendidikan Islam untuk mencapai tujuan pendidikan Islam secara efektif dan efesien (Muhaimin, 2011: 5).

Sedangkan lingkungan pendidikan adalah segala sesuatu yang ada dan terjadi disekeliling proses pendidikan itu berlangsung yang terdiri dari manusia, binatang, tumbuh-tumbuhan, dan benda-benda mati. Keempat kelompok benda-benda lingkungan pendidikan itu ikut berperan dalam rangka usaha setiap siswa/mahasiswa mengembangkan dirinya. Tetapi manajemen pendidikan menaruh perhatiannya terutama kepada lingkungan yang berwujud manusia yaitu masyarakat (Pidarta, 2004).

Tugas manajemen pendidikan antara lain mengintegrasikan dan memanfaatkan lingkungan sebagai sumber-sumber pendidikan dengan seefektif dan seefesien mungkin. Para guru diharapkan dapat mempergunakan dan memanfaatkan sumber-sumber pendidikan tersebut dalam rangka meningkatkan proses belajar-mengajar pada masing-masing sekolah atau lembaga pendidikan dimana mereka bertugas. Dalam hal ini manajer hanya memberikan ramburambu atau petunjuk-petunjuk umum dalam penggunaan lingkungan yang dimaksud (Asnawir, 2006: 355).
Lingkungan pendidikan tersebut selalu mengalami perubahanperubahan. Perubahan tersebut terjadi karena perkembangan ilmu pengetahuan dan teknologi. Perkembangan ilmu pengetahuan dan teknologi tersebut akan mempengaruhi dinamisasi dan mobilisasi individu dan masyarakat yang sekaligus akan berpengaruh terhadap perilaku individu dan masyarakat itu sendiri.

Secara garis besarnya lingkungan tersebut dapat dikelompokkan kepada: (1) lingkungan makro (makro environment) dan lingkungan mikro (mikro environment). Di samping itu lingkungan tersebut juga ada berbentuk lingkungan eksternal (eksternal environment), dan lingkungan internal (internal environment). Lingkungan eksternal itu ada yang langsung (direct environment) dan ada yang bersifat umum (general environment).

Lingkungan eksternal langsung pendidikan adalah lingkungan yang berada di luar kendali lembaga pendidikan, tapi mempunyai pengaruh langsung terhadap kinerja lembaga pendidikan tersebut. Unsur-unsur dari lingkungan eksternal tersebut antara lain: (1) pemasok; (2) pelanggan; (3) penyandang dana; (4) pesaing; dan (5) pemerintah.

Pemasok lembaga pendidikan dapat berbentuk personal maupun nonpersonal. Pemasok yang berbentuk personal adalah calon-calon sebagai input dari lembaga pendidikan yang dimaksud, bahkan kalau pasokan terputus dapat menyebabkan lembaga pendidikan tersebut gulung tikar. oleh sebab itu lembaga pendidikan tersebut harus aktif mengusahakan tersedianya pasokan-pasokan yang dimaksud, dengan jalan melakukan publikasi, sosialisasi kepada masyarakat yang menjadi lingkungan pendidikan (Asnawir, 2006: 357).

\section{Jurnal Al-Thariqah Vol. 1, No. 1, Juni 2016}


Untuk itu manajemen harus dapat menjalin kerjasama yang baik dengan lingkungan atau dengan masyarakat, agar kegiatan proses belajar dan proses pendidikan dapat nerjalan dengan baik dan lancar. Semakin tingginya pasokan dari lingkungan akan semakin terjamin eksisnya lembaga pendidikan yang bersangkutan.

Selanjutnya pelanggan atau konsumen juga akan mempengaruhi terhadap keberadaan lembaga pendidikan. Untuk itu pihak manajemen harus mengamati dan peka terhadap setiap perubahan perilaku dari konsumen tersebut. Dalam kaitan ini lembaga harus berusaha untuk dapat menciptakan agar konsumen merasa puas terhadap output yang dihasilkan oleh lembaga pendidikan dimaksud. Ketidak puasan konsumen akan menyebabkan konsumen berpindah kepada out-put yang dihasilkan oleh lembaga lainnya.

Penyandang dana merupakan unsur yang sangat menentukan terhadap terlaksananya proses pendidikan pada suatu lembaga pendidikan. Untuk itu pihak manaemen pendidikan harus mampu menciptakan hubungan kerjasama dengan badanbadan tertentu, baik secara individu maupun secara kelompok/organisasi untuk dapat memberikan suatu sumbangan/bantuan keuangan kepada lembaga pendidikan bersangkutan. Disamping itu manajemen juga harus untuk memperhatikan gerak-gerik pesaing yang ada. Dengan jalan demikian pihak manajaemen harus dapat menentukan strategi yang tepat untuk digunakan dalam memenangkan persaingan.

Begitu juga kebijakan-kebijakan yang dibuat pemerintah sering bermuatan politis, dan tidak jarang akan mempengaruhi pelaksanaan kegiatan pendidikan. Ada di antara kegiatan politik pemerintah yang menguntungkan pelaksanaan kegiatan pendidikan dan pengajaran atau lembaga pendidikan, dan ada pula yang merugikan pendidikan yang menyebabkan pendidikan tersebut tidak berdaya, bahkan dapat menyebabakan lembaga pendidikan gulung tikar karena sudah kehabisan energi.

Lembaga sosial dan budaya merupakan kekuatan yang secara umum mempengaruhi kehidupan orgainisasi lembaga pendidikan. Dalam kaitan ini pihak manajemen harus menyesuaikan praktek pendidikan dengan harapan masyarakat yang selalu berubah. Perubahan yang terjadi harus selalu dideteksi oleh pihak manajemen.

Lingkungan internal organisasi/ lembaga merupakan kekuatan yang ada dalam organisasi atau lembaga pendidikan yang bersangkutan, yang sifatnya dapat dikontrol oleh manajemen. Lingkungan internal ini sangat berpengaruh terhadap kinerja lembaga pendidikan. Kekuatankekuatan yang ada dalam lingkungan internal tersebut meliputi tenaga akademik dan tenaga administrasi, sarana dan prasarana pendidikan. Pada suatu lembaga pendidikan antar manajer dengan tenaga akademik dan tenaga administrasi mempunyai kepentingan yang selalu terkait antara satu sama lainnya. Dari uraian yang dikemukakan dapat dipahami bahwa antara lingkungan dan organisasi terdapat hubungan yang saling mempengaruhi. Thomson mengemukakan model hubungan tersebut, dimana ada dua dimensi yang saling terkait yaitu: (1) tingkat perubahan, (2) tingkat homogenitas. Tingkat homogenitas mempunyai skala mulai dari yang paling komplek sampai kepada paling sederhana. Begitu juga tingkat perubahan mempunyai skala 
dari stabil dinamis kepada kurang stabil. Tingkat homogenitas yang sederhana dan tingkat perubahan yang stabil dinamis akan melahirkan ketidak pastian yang rendah atau tingkat kepastian yang tinggi. Sebaliknya tingkat homogenitas yang kompleks dan tingkat perubaha yang kurang stabil akan melahirkan ketidak pastian yang tinggi atau kepastian yang rendah.

Tingkat homogenitas dan tingkat perubahan lingkungan dalam ketidak pastian tersebut sangat ditentukan oleh jenis kegiatan yang dilakukan. Suatu lembaga berada dalam kondisi ketidak pastian tinggi apabila organisasi/ lembaga tersebut menghadapi perubahan lingkungan yang cepat dan elemen homogenitas yang sangat kompleks.

Sebaliknya kombinasi perubahan yang dinamis dengan elemen lingkungan yang sederhana menunjukan organisasi berada dalam ketidak pastian moderat. Perbedaan ketidak pastian tersebut menuntut manajer untuk mengambil tindakan antisipasi yang berbeda pula. Semakin besar ketidakpastian lingkungan yang dihadapi oleh lembaga, akan menyebabkan lingkungan semakin membatasi perilaku-perilaku dan kebebasan par manajer untuk menentukan nasib mereka sendiri (Asnawir, 2006: 358-361).

\section{Pentingnya Pemberdayaan Masyara- kat dalam Pendidikan Islam}

Sistem pendidikan yang selama ini dikelola dalam suatu iklim birokratik dan sentralistik dianggap sebagai salah satu sebab yang telah membuahkan keterpurukan dalam mutu dan keunggulan pendidikan di tanah air. Mengapa demikian? Karena sistem birokrasi selalu menempatkan kekuasaan sebagai faktor yang paling menentukan dalam proses pengambilan keputusan. Sekolah-sekolah saat ini telah terkungkung oleh kekuasaan birokrasi yang "menggurita" sejak kekuasaan tingkat pusat hingga daerah, bahkan terkesan semakin buruk dalam era desentralisasi ini. Ironisnya, kepala sekolah dan guru- guru sebagai pihak yang paling memahami realitas pendidikan berada pada tempat yang "dikendalikan". Merekalah seharusnya yang paling berperan sebagai pengambil keputusan dalam mengatasi berbagai persoalan sehari-hari yang menghadang upaya peningkatan mutu pendidikan. Namun, mereka ada dalam posisi tidak berdaya dan tertekan oleh berbagai pembakuan dalam bentuk juklak dan juknis yang "pasti" tidak sesuai dengan kenyataan objektif di masing-masing sekolah. Oleh karena itu, tidaklah berlebihan jika dikatakan bahwa kekuasaan birokrasi persekolahan telah membuat sistem pendidikan kita tidak pernah terhenti dari keterpurukan.

Kekuasaan birokrasi jugalah yang menjadi faktor sebab dan menurunnya semangat partisipasi masyarakat terhadap penyelenggaraan pendidikan di sekolah. Dulu, sekolah sepenuhnya dimiliki oleh masyarakat, dan merekalah yang membangun dan memelihara sekolah, mengadakan sarana pendidikan, serta iuran untuk mengadakan biaya operasional sekolah. Jika sekolah telah mereka bangun, masyarakat hanya meminta guru-guru kepada pemerintah untuk diangkat pada sekolah tersebut. Pada waktu itu, kita sebenarnya telah mencapai pembangunan pendidikan yang berkelanjutan (sustainable development), karena sekolah adalah sepenuhnya milik masyarakat yang senantiasa bertanggung jawab dalam pemeliharaan serta fungsional pendidikan sehari-hari. Pada waktu itu,

\section{Jurnal Al-Thariqah Vol. 1, No. 1, Juni 2016}


pemerintah berfungsi sebagai penyeimbang, melalui pemberian subsidi bantuan bagi sekolah. pada masyarakat yang benar-benar kurang mampu.

Namun, keluarnya Inpres SDN No. 10/1973 adalah titik awal dan keterpurukan sistem pendidikan, terutama sistem persekolahan di tanah air. Pemerintah telah mengambil alih "kepemilikan" sekolah yang sebelumnya milik masyarakat menjadi milik pemerintah dan dikelola sepenuhnya secara birokratik bahkan sentralistik. Sejak itu, secara perlahan "rasa memiliki" dan masyarakat terhadap sekolah menjadi pudar bahkan akhirnya menghilang. Peran masyarakat yang sebelumnya "bertanggung jawab" mulai berubah menjadi hanya "berpartisipasi" terhadap pendidikan, selanjutnya masyarakat bahkan menjadi "asing" terhadap sekolah. Semua sumber daya pendidikan ditanggung oleh pemerintah dan seolah tidak ada alasan bagi masyarakat untuk ikut serta berpartisipasi apalagi bertanggung jawab terhadap penyelenggaraan pendidikan di sekolah (Uno, 2008: 8384).

Kunandar menjelaskan bahwa untuk membuat semua pihak terlibat dan merasa memiliki terhadap sekolah dibutuhkan suasana yang demokratis, dan semua pihak terlibat dalam proses pengambilan keputusan. Dari sinilah lalu muncul ide untuk mendesain sebuah "pendidikan berbasis masyarakat (community-basededucation). Plat form dasar pendidikan berbasis masyarakat adalah penguatan sistem pendidikan di masyarakat dengan serangkaian agenda, yaitu ; Pertama, memobilisasi sumber daya setempat dan dari luar guna meningkatkan peran masyarakat untuk mengambil bagian yang lebih besar dalam perencanaan, implementasi, evaluasi penyelenggaraan pendidikan disemua jalur, jenjang, jenis dan satuan pendidikan. Kedua, menstimulasi perubahan sikap dan persepsi masyarakat terhadap rasa kemitraan, toleransi dan kesediaan menerima keragaman sosial budaya. Ketiga, mendukung masyarakat untuk mengambil peran yang jelas dalam pendidikan terutama orang tua dalam paket kebijakan desentralisasi. Keempat, mendorong peran masyarakat dalam mengembangkan inovasi kelembagaan untuk melengkapi, mempertegas peran sekolah, meningkatkan mutu relevansi, efisiensi manajemen pendidikan, dan membuka kesempatan sekolah yang lebih besar demi program belajar 9 tahun pendidikan dasar, pendidikan menengah, dan pendidikan tinggi (Sagala, 2000: 246-247).

\section{Strategi Pendidikan Islam dalam Menghadapi Perubahan}

Strategi yang dapat digunakan untuk mengahadapi perubahan lingkungan dan ketidak pastian itu melalui beberapa cara antara lain: (1) Melakukan penyesuaian terhadap perubahan lingkungan. Hal semacam ini dapat dilakukan kalau kekuatan lingkungan tidak dapat berubah. Lingkungan/organisasi dapat melakukan penyesuaian dengan mengubah organisasi, yaitu struktur dan desain yang ada; (2) Melakukan pemantauan terhadap lingkungan secara tidak lansung. Dalam kaitan ini para manajer harus melakukan pemantauan terhadap perkembangan dan perubahan lingkungan melalui informasi dari berbagai media; dan (3) Manajer berusaha untuk mempengaruhi lingkungan secara langsung. Hal ini dapat dilakukan dengan melakukan lobi-lobi, pemasangan iklan, dan 
mengadakan kesepakatan dengan pihak-pihak yang terkait.

Selanjutnya manajer tidak hanya bekerja dalam lingkungan internal dan eksternal domestik saja, akan tetapi juga harus memperhatikan kekuatankekuatan global yang mempengaruhin organisasi. Apalagi hal semacam ini perlu dilakukan kalau manajer bekerja dalam organisasi yang lebih luas yang memerlukan dilakukan "go international".

Untuk dapat memenangkan kompetisi dalam era globalisasi ini, maka manajer harus memahami unsurunsur pokok yang berkaitan dengan lingkungan. Di antara unsur-unsur tersebut antara lain: (1) strategi struktur dan persaingan, (2) kondisi permintaan terhadap produk yang dihasilkan, untuk itu perlu diusahakan produk yang bermutu tinggi dan bersifat inovatif, (3) kondisi pekerja, infra struktur ekonomi, raw input, dan sumber daya alam, dan (4) kemampuan menyediakan sumber daya input dan jasa yang diperlukan untuk mendukung produksi yang dihasilkan.

Organisasi pendidikan sebagai suatu system terbuka. Selalu mengadakan kontak atau hubungan dengan lingkungannya. Lingkungan senmacam ini disebut dengan supra system. Organisasi pendidikan sebagai system terbuka, memilki apa yang disebut dengan "negantropy" yaitu suatu usaha yang terus menerus untuk menghalangi terjadinya "entropy". Hal semacam ini menunjukan bahwa hidup atau matinya lembaga pendidikan sebagian besar dilakukan oleh usaha lembaga pendidikan itu sendiri dalam membenahi dirinya.

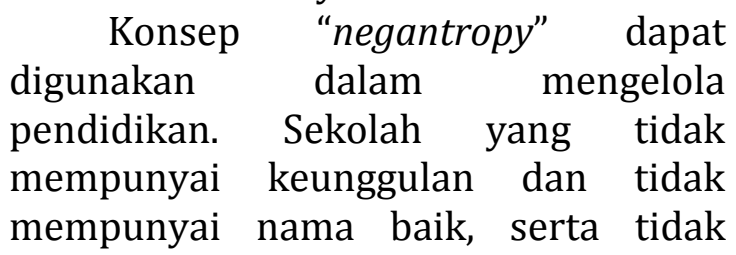

baik, serta tidak mempunyai hubungan baik dengan pendukungnya, tidak akan diminati oleh masyarakat/pendukungnya, yang akhirnya secara pelan-pelan akan mati dengan mati sendirinya.

Oleh sebab itu lembaga pendidikan harus membuka diri dan mengadakan hubungan dengan pihak lain yaitu dengan orang tua dan masyarakat sekitar. Pendidikan adalah tanggung jawab bersama antara pemerintah, orang tua, dan masyarakat. Hubungan pendidikan bukanlah berdiri sendiri dalam membina pertumbuhan dan perkembangan lembaga pendidikan dimaksud, akan tetapi tidak dipisahkan dengan masyarakat luas (asnawir, 2006: 363).

\section{Menggalang Partisipasi Orangtua dan Masyarakat dalam Mengelola Pendidikan Islam}

Partisipasi masyarakat terbelakang terhadap program-program pendidikan yang masih rendah. Hal ini disebabkan karena masih banyak masyarakat yang belum paham akan makna yang berhubungan dengan pendidikan, sehingga mereka tidak menghiraukan kepentingan pendidikan tersebut.

Untuk meningkatkan partisipasi masyarakat terhadap pendidikan, manajer pendidikan harus dapa menggugah perhatian para tokoh-tokoh masyarakat untuk membicarakan persoalan-persolan yang berkitan dengan pendidikan. Dalam pertemuan tersebut akan dilakukan tukar pikiran atau urung rembuk/adu pendapat untuk mendapatkan sebagai alternative yang digunakan untuk peningkatan pendidikan.

Agar sekolah memberikan citra positif kepada masyarakat, maka pihak lembaga pendidikan tidak hanya menyediakan informasi kepada 
masyarakat, tetapi masyarakat memerlukan bukti nyata tentang apa yang telah dilakukan oleh lembaga pendidikan untuk meningkatkan kemampuan dan kemajuan peserta didik. Kalau sekiranya bukti ini telah dapat diperlihatkan kepada masyarakat, maka masyarakat akan memberi dukungan dan sumbangan yang lebih besar kepada lembaga pendidikan tersebur.

Bukti tersebut dapat berupa keberhasilan lembaga pendidikan dalam mengikuti cerdas cemat pada acara-acara televisi, piagam-piagam keberhasilan siswa mengikuti lombalomba yang diadakan seperti lomba olahraga, lomba keterampilanketerampilan, dan lomba pidato adat dan bahasa asing serta lomba lainlainnya.

Begitu juga bukti keberhasilan lembaga pendidikan dapat berupa keberhasilan para lulusan untuk mengikuti persaingan ke sekolah yang lebih tinggi. Hal semacam ini akan dapat meningkatkan perhatian masyarakat dalam memberikan bantuan dan sumbangan yang lebih besar kepada lembaga pendidikan, baik sumbangan dan bantuan dalam bentuk material maupun dalam bentuk non-material. Semakin besar kepuasan yang diterima masyarakat dari sekolah/lembaga pendidikan akan semakin besar pula sumbangan dan bantuan yang diberikan masyarakat kepada lembaga pendidikan tersebut.

Beberapa Negara yang telah menerapkan sistem pengelolaan pendidikan secara desentralisasi, menunjukkan tingginya partisipasi masyarakat terhadap lembaga pendidikan. Partisipasi tersebut terlihat dalam perencanaan, pengorganisasian dan pelaksanaan serta pengawasan kegiatan yang dilakukan oleh lembaga pendidikan yang dimaksud. Begitu juga masyarakat menyadari betapa pentingnya lembaga pendidikan untuk memajukan putra-putri mereka dalam bidang ilmu pengetahuan dan teknologi serta bidang keterampilanketerampilan yang siap pakai dalam usaha melaksanakan pembangunan masyarakat.

Made Pidarta (2004:188) mengemukakan beberapa contoh partisipasi masyarakat terhadap lembaga pendidikan yaitu dengan munculnya beberapa wadah seperti: (1) dewan pendidikan, (2) komite sekolah, (3) persatuan orang tua siswa, (4) perkumpulan olah raga, (5) perkumpulan kesenian, (6) organisasiorganisasi lainnya. Khusus untuk Sumatra barat telah lahir beberapa kegiatan yang bernuansakan keagamaan seperti: (1) pesantren kilat, (2) didikan subuh, dan (3) wirid-wirid remaja dan sebagainya. Kegiatan ini di kota Padang sudah merupakan keharusan.

Partisipasi masyarakat tersebut juga terlihat dalam bidang kurikulum, alat pelajaran, bantuan dana, material, bangunan, kontrol terhadap kegiatankegiatan sekolah dan lain sebagainya. Cara berpartisipasi masyarakat yang dilakukan masyarakat tersebut dapat berbentuk: (1) ikut sertanya dalam pertemuan yang diadakan sekolah/ lembaga pendidikan, (2) datang berkunjung ke sekolah untuk mengamati dan mengetahui keadaan sekolah, (3) melalui surat-surat, (4) melalui telepon, (5) ikut dalam kegiatan kesenian yang dilakukan sekolah, (6) ikut dalam kegiatan bazaar yang dilakukan sekolah, dan (7) terlibata dalam kegiatan-kegiatan lainnya yang dilakukan sekolah.

Keterlibatan masyarakat di perguruan tinggi yaitu adanya dewan penyantun, yayasan perguruan tinggi, dan lain-lain. Dewan penyantun

Jurnal Al-Thariqah Vol. 1, No. 1, Juni 2016 
tersebut meliputi badan-badan yang dibentuk oleh perguran tinggi dan bisanya mendapat legalitas dari senat perguruan tinggi. Anggota-anggota dewan penyantun tersebut berasal dari tokoh-tokoh masyarakat, baik tokohtokoh di bidang social kermasyarakatan, bidang pemerintahan, bidang perusahaan dan bidangbidang lainnya yang dapat memberikan sumbangan kepada perguruan tinggi tersebut, dalam usaha meningkatkan lulusan yang berkualitas, sarana dan prasarana yang dibutuhkan dan lain sebagainya.

Biasanya dewan penyantun tersebut bertugas sebagai penyambung perguruan tinggi dengan masyarakat. Pihak perguruan tinggi dalam hal ini manajer dan anggota dewan penyantun membahas masalah-masalah yang berkaitan dengan perguruan tinggi tersebut. Setelah itu dewan penyantun merealisasikannya ke tengah-tengah masyarakat.

Di samping itu yayasan pendidikan juga berusaha untuk membantu sekolah. Pihak manajer bersama-sama dengan pihak yayasan menangani pendidikan secara keseluruhan. Manajer lebih banyak bergerak dalam penyelenggasraan pendidikan sehari-hari, dan yayasan yang lebih banyak menangani kebijakan dan strategi pendidikan, terutama sekali yang berkaitan dengan dana yang ditujukan agar lembaga pendidikan tersebut tetap eksist.

Uraian diatas menunjukkan perlu adanya kerjasama antara lembaga pendidikan dan masyarakat. Lembaga pendidikan berusaha untuk memberi layanan kepada masyarakat sebaik mungkin, sedangkan masyarakat berusaha untuk memenuhi kebutuhan lembaga pendidikan. Begitu juga masyarakat ikut berpartisipasi membantu lembaga pendidikan. Demi kemajuan dan kelangsungan hidup lembaga pendidikan yang dimaksud.

Kerjasama dimaksud akan dapat terwujud kalau sekiranya tetap tercipta dan terwujud komunikasi dua arah (two ways communication). Dalam hal ini sangat dituntut peranan aktif kepala sekolah untuk dapat menciptakan komunikasi yang baik dengan masyarakat. Sehubungan dengan itu dalam pembuatan program harus diperhatikanbeberapa persyaratan, dimana program tersebut harus dibuat secara jujur, mulia, mencakup segala yang diperlukan, komprehensif, sensitive terhadap masyarakat, dan dapat dipahami. Disamping itu Made Pidarta (2004:195-196) mengemukakan beberapa kegiatan yang dapat dilakukan dalam menciptakan komunikasi antara sekolah dan masyarakat, yaitu melalui: (1) Aktivitas peserta didik; (2) Aktivitas ko dan ekstra kurikuler; (3) Aktivitas para pengajar/guru-guru; (4) Media masa; (5) Kunjungan warga masyarakat ke lembaga pendidikan; (6) Pertemuanpertemuan dengan masyarakat; dan (7)Aktivitas-aktivitas khusus persahabatan (Asnawir, 2006: 366-370).

\section{Peran Dewan Pendidikan dan Komite Sekolah dalam Meningkatkan Mutu Pendidikan Islam}

Peran dan fungsi Dewan Pendidikan dan Komite Sekolah tidak dapat dipisahkan dari aspek pelaksanaan manajemen pendidikan di tingkat sekolah. Beberapa aspek manajemen yang secara langsung dapat diserahkan sebagai urusan yang menjadi kewenangan tingkat sekolah adalah sebagai berikut.

Pertama, menetapkan visi, misi, strategi, tujuan, logo, lagu dan tata tertib sekolah. Urusan ini amat penting sebagai modal dasar yang harus dimiliki

\section{Jurnal Al-Thariqah Vol. 1, No. 1, Juni 2016}


sekolah. Setiap sekolah seyogianya telah dapat menyusun dan menetapkan sendiri visi, misi, strategi, tujuan, logo, lagu, dan tata tertib sekolah. Ini merupakan bukti kemandirian awal yang harus ditunjukkan oleh sekolah. Jika masa lalu sekolah lebih dipandang sebagai lembaga birokrasi yang selalu menunggu perintah dan petunjuk dari atas, dalam era otonomi daerah ini sekolah harus telah memiliki kesadaran untuk menentukan jalan hidupnya sendiri. Dalam hal ini, sekolah harus menjalin kerja sama sebaik mungkin dengan orang tua dan masyarakat sebagai mitra kerjanya. Bahkan, dalam menyusun program kerjanya sebagai penjabaran lebih lanjut dari visi, misi strategi, dan tujuan sekolah tersebut, orang tua dan masyarakat yang tergabung dalam Komite Sekolah, serta seluruh warga sekolah harus dilibatkan secara aktif dalam menyusun program kerja sekolah, dan sekaligus lengkap dengan Rencana Anggaran Pendapatan dan Belanja Sekolah (RAPBS).

Kedua, memiliki kewenangan dalam penerimaan siswa baru sesuai dengan ruang kelas yang tersedia, fasilitas yang ada, jumlah guru, dan tenaga administratif yang dimiliki. Berdasarkan sumber daya pendukung yang dimilikinya, sekolah secara bertanggung jawab harus dapat menentukan sendiri jumlah siswa yang akan diterima, syarat siswa yang akan diterima, dan persyaratan lain yang terkait. Beberapa ketentuan yang ditetapkan oleh dinas pendidikan kabupaten/kota tentu saja perlu mendapatkan pertimbangan secara bijak.

Ketiga, menetapkan kegiatan intrakurikuler dan ekstrakurikuler yang akan diadakan dan dilaksanakan oleh sekolah. Dalam hal ini, dengan mempertimbangkan kepentingan daerah dan masa depan lulusannya, sekolah perlu diberikan kewenangan untuk melaksanakan kurikulum nasional dengan kemungkinan menambah atau mengurangi muatan kurikulum dengan meminta pertimbangan kepada Komite Sekolah. Kurikulum muatan lokal, misalnya dalam mengambil kebijakan untuk menambah mata pelajaran seperti bahasa Inggris dan bahasa asing lainnya, komputer, dan sebagainya. Kebijakan tersebut setelah meminta pertimbangan dari Komite Sekolah, termasuk risiko anggaran yang diperlukannya. Dalam kaitannya dengan penetapan kegiatan ekstrakurikuler, sekolah juga harus meminta pendapat siswa dalam menentukan kegiatan eksrakurikuler yang diadakan oleh sekolah.

Oleh karena itu, sekolah dapat melakukan pengelolaan biaya operasional sekolah, baik yang bersumber dari pemerintah Kabupaten/kota maupun dari masyarakat secara mandiri. Untuk mendukung program sekolah yang telah disepakati oleh Komite Sekolah diperlukan ketetapan waktu dalam pencairan dana dari pemerintah kabupaten/kota. Oleh karena itu, praktik birokrasi yang menghambat kegiatan sekolah harus dikurangi.

Keempat, pengadaan sarana dan prasarana pendidikan, termasuk buku pembelajaran dapat diberikan kepada sekolah, dengan memerhatikan standar dan ketentuan yang ada. Misalnya, buku murid tidak seenaknya diganti setiap tahun oleh sekolah, atau buku murid yang akan dibeli oleh sekolah adalah yang telah lulus penilaian. Pemilihan dan pengadaan sarana dan prasarana pendidikan di sekolah dapat dilaksanakan oleh sekolah, dengan tetap mengacu pada standar dan pedoman yang ditetapkan oleh 
Pemerintah Pusat atau provinsi dan kabupaten/kota.

Kelima, penghapusan barang dan jasa dapat dilaksanakan sendiri oleh sekolah, dengan mengikuti pedoman yang ditetapkan oleh pemerintah provinsi dan kabupaten. Hal yang biasa terjadi, karena kewenangan penghapusan itu tidak jelas, barang dan jasa yang ada di sekolah tidak pernah dihapuskan, meskipun ternyata barang dan jasa sama sekali telah tidak berfungsi atau malah telah tidak ada barangnya.

Keenam, proses pengajaran dan pembelajaran. ini merupakan kewenangan profesional sejati yang dimiliki oleh lembaga pendidikan sekolah. Kepala sekolah dengan guru secara bersama-sama merancang proses pengajaran dan pembelajaran yang memungkinkan peserta didik dapat belajar dengan lancar dan berhasil. Proses pembelajaran yang aktif, kreatif, efektif, dan menyenangkan direkomendasikan sebagai model pembelajaran yang akan dilaksanakan oleh sekolah. Pada masa sentralisasi pendidikan, proses pembelajaran pun diatur secara rinci dalam kurikulum nasional. Dalam era otonomi daerah, kurikulum nasional menjadi kurikulum berbasis kompetensi (KBK). Dan selanjutnya berkembang menjadi Kurikulum Tingkat Satuan Pendidikan (KTSP). Dan pada tahun 2013 direncanakan terjadinya perubahan kurikulum (Uno, 2008: 90).

Ketujuh, urusan teknis edukatif yang lain sejalan dengan konsep manajemen peningkatan nutu berbasis sekolah (MPMBS) merupakan urusan yang sejak awal harus menjadi tanggung jawab dan kewenangan setiap satuan pendidikan.

\section{Pemberdayaan Komite Sekolah dan Dewan Pendidikan}

Desentralisasi pendidikan di tingkat seklah merupakan satu bentuk desentralisasi yang langsung sampai ke ujung tombak pendidikan di lapangan. Jika kantor cabang dinas pendidikan kecamatan dan dinas pendidikan kabupaten/kota lebih memiliki peran sebagai fasilitator dalam proses pembinaan, pengarahan, pemantauan, dan penilaian maka sekolah seharusnya diberikan peran nyata dalam perencanaan, pelaksanaan, pelaporan. Hal ini disebabkan proses interaksi edukatif di sekolah merupakan inti dari proses pendidikan yang sebenarnya. Oleh karena itu, bentuk desentralisasi pendidikan yang paling mendasar adalah yang dilaksanakan oleh sekolah, dengan menggunakan Komite Sekolah sebagai wadah pemberdayaan peran serta masyarakat, dan dengan menerapkan manajemen berbasis sekolah (MBS) sebagai proses pelaksanaan layanan pendidikan secra nyata di dalam masyarakat.

Berdasarkan Undang-undang Nomor 25 Tahun 2000 tentang Program Pembangunan Nasional (Propenas) 2000-2004, dalam rangka pemberdayaan dan peningkatan peran serta masyarakat perlu dibentuk Dewan Pendidikan di tingkat kabupaten/kota dan Komite Sekolah di tingkat satuan pendidikan. Amanat rakyat ini sejalan dengan konsepsi desentralisasi pendidikan, baik di tingkat kabupaten/kota maupun di tingkat sekolah. Amanat rakyat dalam undangundang tersebut telah ditindaklanjuti dengan Keputusan Menteri Pendidikan Nasional Nomor 044/U/2002 tanggal 2 April 2002 tentang Dewan Pendidikan dan Komite Sekolah. Dalam Kepmendiknas tersebut disebutkan bahwa peran yang harus diemban Dewan Pendidikan dan Komite Sekolah adalah sebagai (1) advisory agency (pemberi pertimbangan), (2) supporting

Jurnal Al-Thariqah Vol. 1, No. 1, Juni 2016 
agency (pendukung kegiatan layanan pendidikan), (3) controlling agency (pengontrol kegiatan layanan pendidikan), dan (4) mediator (penghubung atau pengait tali komunikasi antara masyarakat dengan pemerintah).

Untuk dapat memberdayakan dan meningkatkan peran masyarakat, sekollah harus dapat membina kerja sama dengan orang tua, dan masyarakat, menciptakan suasana kondusif dan menyenangkan bagi peserta didik dan warga sekolah. Itulah sebabnya paradigma MBS mengandung makna sebagai manajemen partisipatif yang melibatkan peran serta masyarakat sehingga semua kebijakan dan keputusan yang diambil adalah kebijakan dan keputusan bersama, untuk mencapai keberhasilan bersama. Dengan kemudian, prinsip kemandirian dalam MBS adalah kemandirian dalam nuansa kebersamaan. Hal ini merupakan aplikasi dari prinsip-prinsip yang disebut sebagai total quality management, melalui suatu mekanisme yang dikenal dengan konsepsi total football dengan menekankan pada mobilisasi kekuatan secara sinergis yang mengarah pada satu tujuan, yaitu peningkatan mutu dan kesesuaian pendidikan dengan pengembangan masyarakat.

\section{Penyusunan Rencana dan Program}

Sebagai ujung tombak dalam pelaksanaan pendidikan, sekolah bertanggungjawab menentukan kebijakan sekolah dalam melaksanakan kebijakan pendidikan sesuai dengan arah kebijakan pendidikan yang telah ditentukan oleh pemerintah. Sebagai penyelenggara dan pelaksana kebijakan pendidikan nasional, sekolah bertugas menjabarkan kebijakan pendidikan nasional menjadi program-program operasional penyelenggaraan pendidikan di masing-masing sekolah. Program-program tersebut terdiri dari penyusunan dan pelaksanaan rencana kegiatan mingguan, bulanan, semesteran, serta tahunan yang sesuai dengan arah kebijakan serta kurikulum yang telah ditetapkan, baik pada tingkat pusat, provinsi, maupun kabupaten/ kota. Setiap rencana dan program yang disusun serta dilaksanakan di sekolah harus mengacu pada standar pelayanan minimum (SPM) yang diterapkan untuk pemerintah kabupaten/kota serta standar teknis yang diterapkan untuk masing-masing satuan pendidikan. Untuk dapat memerankan fungsi ini, Komite Sekolah menjadi "pendamping" bahkan "penyeimbang" bagi sekolahsekolah. Oleh karena itu, setiap rencana dan program yang disusun oleh sekolah dapat diberikan masukan yang sesuai dengan aspirasi masyarakat yang diwakili oleh Komite Sekolah yang dimaksud. Atas nama masyarakat yang diwakilinya, Komite Sekolah dapat menyatakan "setuju" atau "tidak setuju" terhadap rencana dan program pendidikan yang disusun oleh sekolah.

Selain melaksanakan kurikulum yang telah ditetapkan dari pusat, provinsi, dan kabupaten/kota, sekolahsekolah dapat juga menyusun program pendidikan life skill yang sesuai dengan keadaan dan kebutuhan pada masyarakat sekitar. Dalam penyusunan program pendidikan life skill, Komite Sekolah dapat membantu sekolahsekolah untuk mengumpulkan faktafakta mengenai kebutuhan serta potensi sumber daya tersedia di dalam masyarakat untuk diterjemahkan ke dalam program pendidikan life skill yang dapat dilaksanakan oleh sekolah. Mekanisme yang mungkin dapat dilakukan adalah melalui rapat Komite Sekolah dengan sekolah yang dilaksanakan setiap semester atau

\section{Jurnal Al-Thariqah Vol. 1, No. 1, Juni 2016}


tahunan, untuk menyusun, memperbaiki serta menyesuaikan rencana dan program semester berikutnya.

\section{Penyusunan Rancangan Anggaran Pendapatan dan Belanja Sekolah (RAPBS)}

Dalam fungsi sebagai pelaksana pendidikan yang otonom, sekolah berperan dalam menyusun RAPBS setiap akhir tahun ajaran untuk digunakan dalam tahun ajaran berikutnya. Program-program yang sudah dirumuskan untuk satu semester atau satu tahun ajaran ke depan perlu dituangkan ke dalam kegiatan-kegiatan serta anggarannya masing-masing sesuai dengan pos-pos pengeluaran pendidikan di tingkat sekolah. Dari sisi pendapatan, seluruh jenis dan sumber pendapatan yang diperoleh sekolah setiap tahun harus dituangkan dalam RAPBS, baik yang bersumber dari pemerintah pusat, pemerintah pusat, pemerintah provinsi, pemerintah kabupaten/kecamatan, maupun bersumber-sumber lain yang diperoleh secara langsung oleh sekolah-sekolah. Dengan demikian, setiap rupiah yang diperoleh sekolah dari sumber-sumber tersebut harus sepenuhnya diperhitungkan sebagai pendapatan resmi sekolah dan diketahui bersama, baik oleh pihak sekolah (kepala sekolah, guru-guru, pegawai, serta para siswa) maupun oleh Komite Sekolah sebagai wakil stakeholder pendidikan.

Dari sisi belanja sekolah, seluruh jenis pengeluaran untuk kegiatan pendidikan di sekolah harus diketahui bersama, baik oleh pihak sekolah maupu oleh pihak Komite Sekolah, sesuai dengan rencana dan program yang telah disusun bersama oleh kedua pihak tersebut. Kedua sisi anggaran tersebut dituangkan ke dalam suatu neraca tahunan sekolah yang disebut dengan RAPBS, yang harus disahkan atas dasar persetujuan bersama antara pihak sekolah dan Komite Sekolah yang ditandatangani oleh kepala sekolah dan ketua Komite Sekolah sehingga menjadi APBS pendidikan di tingkat sekolah yang resmi. Mekanisme ini diperlukan untuk memperkecil penyalahgunaan, baik dalam pendapatan maupun dalam pengeluaran sekolah sehingga anggaran resmi pendidikan di sekolah menjadi bertambah serta pendayagunaannya semakin efisien.

\section{Pelaksanaan Program Pendidikan}

Sistem pendidikan pada masa orde baru, pelaksanaan pendidikan secara langsung dikendalikan oleh sistem birokrasi dengan mata rantai yang panjang mulai dari tingkat pusat, daerah, bahkan sampai tingkat satuan pendidikan. Pada waktu itu, sekolahsekolah adalah bagian dari sistem birokrasi yang harus tunduk terhadap ketentuan birokrasi. Pengaturan penyelenggaraan pendidikan pada masa birokrasi dilakukan secara uniform (one fits for all) atau dilakukan secara baku dengan pengaturan dari pusat, mulai dari perencanaan pendidikan, pelaksanaan pendidikan di sekolah termasuk persiapan mengajar, metodologi dan pendekatan mengajar, buku dan sarana pendidikan, sampai pada penilaian pendidikan. Dengan kata lain, kepada sekolah-sekolah tidak diberikan kesempatan untuk mengurus dan mengatur dirinya sendiri dalam pelaksanaan pendidikan. Kepala sekolah tidak diberikan kesempatan untuk mengambil keputusan sendiri dalam mengelola sistem pendidikan untuk memecahkan berbagai permasalahan pendidikan yang sesuai dengan kondisi sekolahnya masingmasing. Kepada guru-guru juga tidak diberikan kesempatan untuk berinisiatif

\section{Jurnal Al-Thariqah Vol. 1, No. 1, Juni 2016}


atau berinovasi dalam melaksanakan pengajaran atau mengelola kegiatan belajar murid secara maksimal karena metode mengajar dan teknik evaluasi diatur secara langsung melalui juklak dan juknis yang dibuat dari pusat.

Dalam masa desentralisasi pendidikan ke depan, melalui paradigma MBS sekolah-sekolah diberikan kesempatan seluas-luasnya untuk mengurus dan mengatur pelaksanaan pendidikan pada masingmasing sekolah. Pelaksanaan pendidikan di sekolah-sekolah dalam tempat yang berlainan dimungkinkan untuk menggunakan sistem dan pendekatan pembelajaran yang berlainan. Kepala sekolah diberikan keleluasaan untuk mengelola pendidikan dengan jalan mengadakan serta memanfaatkan sumber-sumber daya pendidikan sendiri-sendiri asalkan sesuai dengan kebijakan dan standar yang ditetapkan oleh pusat. Dikarenakan karakteristik setiap murid juga berbeda-beda secara individual maka pendekatan pembelajaran pun dimungkinkan berbeda untuk masingmasing murid yang berlainan.

Dalam keadaan seperti itu maka Dewan Pendidikan dan Komite Sekolah akan dapat melaksanakan peran dan fungsinya sebagai penunjang dalam pelaksanaan proses pembelajaran yang sejalan dengan kondisi dan permasalahan lingkungan masingmasing sekolah. Komite Sekolah dapat melaksanakan fungsinya sebagai partner dari kepala sekolah dalam mengadakan sumber-sumber daya pendidikan dalam rangka melaksanakan pelaksanaan pengelolaan pendidikan yang dapat memberikan fasilitas bagi guru-guru dan murid untuk belajar sebanyak mungkin, sehingga pembelajaran menjadi semakin efektif. Komite Sekolah bisa ikut serta untuk meneliti berbagai permasalahan belajar yang dihadapi oleh murid secara kelompok maupun secara individual sehingga dapat membantu guru-guru untuk menerapkan pendekatan belajar yang tepat bagi murid-muridnya. Dewan Pendidikan pada setiap kabupaten/kota dapat melaksanakan program pendukung dalam bentuk studi atau penelitian terhadap berbagai permasalahan pendidikan di sekolahsekolah agar dapat memberikan masukan kepada Dinas Kabupaten/Kota untuk menerapkan suatu kebijakan yang tepat dan kena sasaran. Dewan Pendidikan juga dapat memberikan penilaian kepada berbagai kebijakan pendidikan yang diterapkan, terutama rnenyangkut berbagai dampak yang sudah atau mungkin terjadi dalam pecerapan suatu kebijakan baru.

\section{Akuntabliltas Pendidikan}

Pada masa orde baru, satusatunya pihak yang berwenang untuk meminta pertanggungjawaban pendidikan ke sekolah-sekolah adalah pemerintah pusat. Pada waktu itu, pemerintah pusat telah menempatkan "kaki tangan"nya di seluruh pelosok tanah air melalui pemeriksa, pengawas, atau para pemilik sekolah untuk mengawasi dan meminta pertanggungjawaban sekolah-sekolah mengenai proses pendidikan yang berlangsung di sekolah-sekolah. Jika terdapat "penyimpangan administratif" yang dilakukan oleh kepala sekolah atau guru-guru maka kepada mereka diberikan sanksi administratif seperti teguran resmi, penilaian melalui DPK, penundaan kenaikan gaji berkala, penundaan kenaikan pangkat, dan sejenisnya. Namun, penilaian tersebut lebih banyak diberikan terhadap proses administrasi pendidikan dan hampir tidak pernah ada sanksi (punishment)

\section{Jurnal Al-Thariqah Vol. 1, No. 1, Juni 2016}


atau ganjaran (rewards) kepada guruguru atau kepala sekolah atas dasar hasil-hasil yang dicapai dalam pembelajaran murid atau lulusan.

Dalam era demokrasi dan partisipasi, akuntabilitas pendidikan tidak hanya terletak pada pemerintah, tetapi bahkan harus lebih banyak pada masyarakat sebagai stakeholder pendidikan. Dewan Pendidikan pada tingkat Kabupaten/Kota perlu menempatkan fungsinya sebagai wakil dan masyarakat untuk meminta pertanggungjawaban atas hasil pendidikan dalam mencapai prestasi belajar murid-murid pada setiap jenis dan jenjang pendidikan. Dewan Pendidikan perlu diberikan kesempatan untuk menyampaikan masukan bahkan "protes" kepada Dinas Pendidikan jika hasil pendidikannya tidak memuaskan masyarakat sebagai klien pendidikan. Sama halnya, Komite Sekolah dapat menyampaikan ketidakpuasan para orang tua murid akan rendahnya prestasi yang dicapai oleh suatu sekolah. Dewan Pendidikan atau Komite Sekolah tidak perlu melaksanakan kegiatan studi atau penilaian pendidikan, tetapi cukup dengan menggunakan data-data yang tersedia atau hasil-hasil penilaian yang sudah ada sebagai bahan untuk menyampaikan kepuasan atau ketidakpuasan masyarakat terhadap Dinas Pendidikan atau kepada masingmasing sekolah. Dengan demikian, diperlukan suatu mekanisme akuntabilitas pendidikan yang dibentuk melalui suatu Peraturan Daerah di bidang pendidikan (Uno, 2008: 91-96).

\section{SIMPULAN}

Lingkungan pendidikan Islam memerlukan manajemen yang baik sehingga tujuan pendidikan bisa terwujud. Untuk majunya sekolah diperlukan adanya kerjasama sekolah dan masyarakat. Partisipasi masyarakat demi kemajuan sekolah pada saat sekarang ini dengan dibentuknya Dewan Pendidikan dan Komite Sekolah. Ini menunjukkan bahwa semua pihak mesti merasa memiliki sekolah dan percaya bahwa peserta didik akan mampu mengembangkan potensi yang dimiliki dengan bantuan para guru dan perhatian dari orang tua serta adanya penilaian yang seimbang dari stakeholder.

\section{DAFTAR RUJUKAN}

Abbas, Syahrizal. 2008. Manajemen Perguruan Tinggi, Beberapa Catatan. Jakarta: Prenada Media Group.

Asnawir 2006. Manajemen Pendidikan. Padang: IAIN IB Press.

Departemen Pendidikan Nasional. 2001. Kamus Besar Bahasa Indonesia. Jakarta: Balai Pustaka.

Fadjar, A. Malik. 2000. Holistika Pemikiran Pendidikan, Jakarta : PT. Raja Grafindo Persada.

Handoko, T. Hani. 2003. Manajemen. Yogyakarta: BPFE- Yogyakarta.

Kunandar. 2007. Guru Profesional, Implementasi Kurikulum Tingkat Satuan Pendidikan (KTSP) dan Sukses dalam Penelitian Guru. Jakarta: Raja Grafindo Persada.

Muhaimin, et al, 2011. Manajemen Pendidikan Aplikasinya dalam Penyusunan Rencana Pengembangan Sekolah/ Madrasah. Jakarta: Kencana.

Mulyasa, E., 2012. Manajemen dan Kepemimpinan Kepala Sekolah. Jakarta: Bumi Aksara.

Pidarta, Made. 2004. Manajemen Pendidikan Indonesia. Jakarta: Rineka Cipta. 
Sagala, Syaiful. 2000. Kemampuan Profesional Guru dan Tenaga Kependidikan. Bandung: Alfabeta.
Uno, Hamzah B., 2008. Profesi Kependidikan, Problema, Solusi, dan Reformasi Pendidikan di Indonesia. Jakarta: Bumi Aksara.

Jurnal Al-Thariqah Vol. 1, No. 1, Juni 2016 